\title{
PENGARUH TERAPI BEKAM KERING TERHADAP KELUHAN NYERI PUNGGUNG BAWAH PADA PENGERAJIN WANCI DI DESA BRESELA KECAMATAN PAYANGAN
}

\author{
Ni Kadek Yuni Lestari'1, I Nyoman Edi Sastrawan² \\ 1,2STIKes Wira Medika Bali \\ Email: 1yunilestariwika@gmail.com
}

\begin{abstract}
ABSTRAK
Pendahuluan: Nyeri Punggung Bawah adalah rasa nyeri yang dirasakan di daerah punggung bawah dapat merupakan nyeri lokal maupun nyeri radikuler maupun keduanya. Salah satu jenis terapi komplementer dalam mengatasi nyeri adalah terapi bekam kering. Tujuan penelitian ini untuk mengetahui pengaruh terapi bekam kering terhadap keluhan nyeri punggung bawah. Metode: Penelitian ini menggunakan metode pra-eksperimen dengan rancangan one group pre test- post test. Sampel dalam penelitian ini didapatkan 22 orang dengan tehnik non-probability yaitu purposive sampling. Hasil penelitian didapatkan rerata skala nyeri sebelum diberikan terapi bekam kering yakni 3,09 dan rerata skala nyeri setelah diberikan terapi bekam kering yakni 1,50. Hasil uji statistik Wilcoxon Signed Rank Test dengan tingkat kemaknaan 0,05 menunjukkan nilai $\mathrm{p}=0,000$ yang berarti ada pengaruh terapi bekam kering terhadap keluhan nyeri punggung bawah pada pengerajin wanci di desa bresela kecamatan payangan. Kesimpulan: Berdasarkan hasil penelitian tersebut disarankan kepada masyarakat untuk menggunakan terapi komplementer bekam kering sebagai terapi alternative untuk mengurangi keluhan nyeri.
\end{abstract}

Kata kunci: Bekam Kering, Nyeri Punggung Bawah, Pengerajin Wanci.

\begin{abstract}
Introduction: Lower Back Pain is a pain that felt in the lower back area, it can be local pain or radicullar pain and also both of them. One of the type of complementary therapy in order to solve that pain is dry cupping therapy. The purpose of this study is finding out the effect of dry cupping therapy toward the low back pain problem. Method: The study uses pre-experimental method with one group pre-test post test design. The sample design in this study found twenty-two participants with non-probability in kinds of purposive sampling technique. The result of the study found the average of pain scale before giving dry cupping therapy is 3.09 and the average of pain scale after giving dry cupping therapy is decreasing into 1.50. The result of statistical test of Wilcoxon Signed Rank Test with 0.05 significant level showed the P level $=0.000$. There is effect of dry cupping therapy toward the low back pain problem on Wanci worker in Bresela Village, Payangan subdistrict. Based on the findings of this study, the people are suggested to use complementary therapy in order to solve bottom backache problem.
\end{abstract}

Keywords: Dry Cupping, Lower Back Pain, Transporters Workers.

Alamat Korespondensi: STIKes Wira Medika Bali

Email: 1yunilestariwika@gmail.com 


\section{PENDAHULUAN}

Kesehatan adalah suatu keadaan yang sehat baik secara fisik, mental, spiritual mapun sosial yang memungkinkan setiap orang untuk hidup produktif secara sosial dan ekonomis (Dikutip dari UU Kesehatan No. 36 tahun 2009). Kesehatan kerja merupakan kesehatan yang ditujukan untuk melindung pekerja agar hidup sehat dan terbebas dari gangguan kesehatan serta pengaruh buruk yang diakibatkan oleh pekerjaan (Kemenkes, 2014). Penerapan ergonomi di lingkungan kerja merupakan salah satu upaya kesehatan dan keselamatan kerja. Ergonomi mempelajari cara-cara penyesuaian pekerjaan, alat kerja dan lingkungan kerja. Alat kerja dan lingkungan fisik yang tidak sesuai dengan kemampuan alamiah tenaga kerja akan menyebabkan hasil kerja tidak optimal, bahkan berpotensi menimbulkan keluhan kesehatan dan penyakit kerja (Anies, 2014)

Pengerajin adalah orang yang membuat barang-barang kerajinan atau orang yang mempunyai keterampilan berkaitan dengan kerajinan tertentu, barang yang dibuat tidak menggunakan mesin tetapi dengan tangan sehingga sering disebut barang kerajinan tangan (Tjiptoheriyanto, 2008). Berdasarkan hasil survey yang dilakukan Depkes RI (2014) pada bulan Desember di wilayah Jabodetabek, pengerajin yang mengaku sakit selama satu bulan terakhir sebanyak $43 \%$. Pengerajin yang menderita gangguan pernapasan sebesar 13\%, pegal linu $24 \%$ dan nyeri punggung bawah sebesar 33,77\%.

Nyeri punggung bawah adalah suatu sindroma klinik yang ditandai dengan gejala utama nyeri atau perasaan lain yang tidak enak di daerah tulang punggung bagian bawah (Bimariotejo, 2009). Nyeri punggung bawah atau Low Back Pain (LBP) merupakan sindroma klinik dengan gejala utama nyeri atau perasaan tidak nyaman pada daerah tulang punggung bawah. Low Back Pain (LBP) tidak mengenal perbedaan umur, jenis kelamin, pekerjaan, status sosial, dan tingkat pendidikan. Nyeri punggung bawah ini bisa akut, sub akut, atau kronis berdasarkan durasi (Kompas, 2012).

Menurut World Health Organisation (WHO) bahwa 2 - 5\% dari karyawan di negaranegara maju masyarakatnya tiap tahun mengalami nyeri punggung bawah dan $15 \%$ dari pekerja di industri baja serta industri pedagang mengalami nyeri punggung bawah. Data statistik Amerika serikat memperlihatkan angka kejadian nyeri punggung bawah sebesar 15 - $20 \%$ per tahun. Sebanyak $90 \%$ kas reri punggung bukan disebabkan oleh kelainan organik, melainkan oleh kesalahan puve tubuh dalam bekerja, seperti posisi duduk yang salah dan duduk yang terlalu lama (Muheri, 2010). Di Indonesia, Low Back Pain (LBP) lebih sering dijumpai pada golongan usia 40 tahun. Secara keseluruhan Low Back Pain (LBP) merupakan keluhan yang paling banyak dijumpai dengan angka prevalensi mencapai $49 \%$. Akan tetapi sekitar 80-90\% dari mereka yang mengalami Low Back Pain (LBP) menyatakan tidak melakukan usaha apapun untuk mengatasi timbulnya gejala tersebut. Dengan kata lain, hanya sekitar $10-20 \%$ dari mereka yang mencari perawatan medis ke pelayanan kesehatan (Purnamasari, 2010).

Data di Bali menunjukkan 46,1\% sering mengeluhkan nyeri punggung bawah terutama pada usia 30-40 tahun, karena pada usia ini nyeri punggung bawah yang dirasakan erat kaitannya dengan pekerjaan dan aktivitas fisik (Dinas Kesehatan, 2012). Data yang didapat dari poliklinik Rehabilitasi Medik Rumah Sakit Umum Pusat Sanglah Denpasar pada tahun 2012 jumlah pasien nyeri punggung bawah yang menjalani rawat jalan sebanyak 152 pasien (Kurniasih, 2013).

Penelitian yang telah dilakukan oleh Amaluna (2014) dengan judul "Pengaruh Terapi Bekam dan Muscle Energy Technique Terhadap Keluhan Nyeri Bahu Pada Pengerajin Laundry". Penelitian ini menunjukkan hasil terapi bekam dan muscle energy technique terhadap keluhan nyeri bahu sebesar $71 \%$ dan muscle energy technique menurunkan nyeri bahu sebesar $25 \%$, dan penelitian yang dilakukan oleh Juwita, A. F. (2014) menunjukan adanya penurunan nyeri bahu pada buruh wanita setelah dilakukan terapi bekam, dimana 
rata-rata skala nyeri responden sebelum dilakukan perlakuan sebesar 4,06 dan setelah dilakukan terapi bekam menurun dengan rata-rata 1,35. Hal tersebut menunjukan adanya pengaruh yang signifikan perlakuan terapi bekam dalam hal penurunan skala nyeri pada pekerja.

Studi pendahuluan telah dilakukan dilingkungan tempat-tempat bekerja pembuat wanci di Desa Bresela Kecamatan Payangan melalui wawancara secara langsung kepada 10 pengerajin, didapatkan $70 \%$ pengerajin mengatakan bahwa dirinya mengalami punggung dibagian bawah dengan skala nyeri 5-6, terutama setelah membuat wanci yang banyak sedangkan sebanyak $30 \%$ pengerajin tidak mengeluhkan nyeri. Usaha yang dilakukan para pengerajin untuk menangani nyeri punggung bawah yang mereka alami tersebut bervariasi, ada yang mengatakan diperiksakan ke dokter sebanyak $20 \%$, diurut sendiri sebanyak $50 \%$ dan tidak melakukan usaha apapun sebanyak 30\%.

Berdasarkan kondisi permasalahan tersebut, maka penulis merasa tertarik mengadakan penelitian dengan judul "Pengaruh Terapi Bekam Terhadap Keluhan Nyeri Punggung Bawah Pada Pengerajin Wanci di Desa Bresela Kecamatan Payangan”

\section{METODE PENELITIAN}

Metode penelitian yang di gunakan oleh peneliti adalah metode pra-eksperimental dengan menggunakan rancangan one group pretest-posttes design (Sugiyono, 2013). Pre test dilakukan sebelum pemberian intervensi terapi bekam kering, kemudian 5 menit setelah pemberian intervensi dilakukan post test sebagai test akhir. Berdasarkan jenis dan rancangan tersebut sampel dibagi menjadi dua kelompok, satu kelompok merupakan kelompok perlakuan dan satu kelompok sebagai kelompok kontrol. Teknik sampling yang dipakai adalah non-probability sampling dengan teknik purposive sampling yaitu suatu teknik menentukan sampel dengan cara memilih sampel di antara populasi sesuai dengan pertimbangan tertentu atau dikehendaki peneliti sesuai dengan kriteria inklusi dan eksklusi. Populasi adalah wilayah generalisasi yang terdiri atas objek atau subjek yang mempunyai kualitas atau karakteristik tertentu yang ditetapkan oleh peneliti untuk dipelajari dan kemudian ditarik kesimpulannya (Nursalam, 2013). Populasi yang digunakan dalam penelitian ini sebanyak 46 orang pengerajin wanci di desa bresela kecamatan payangan dengan keluhan nyeri punggung bawah. Sampel yang digunakan dalam penelitian ini yaitu pengrajin wanci di desa bresela kecamatan payangan tahun 2018 sesuai dengan kriteria inklusi dan eksklusi sebanyak 22 responden.

\section{HASIL}

Analisa data merupakan suatu proses atau analisa yang dilakukan secara sistematis terhadap data yang telah dikumpulkan. Data disajikan dalam tabel berikut.

Berdasarkan tabel 1, dapat dilihat bahwa responden sebagian besar berada pada rentang umur 35-39 tahun yaitu sebanyak 11 responden $(28,9 \%)$.

Tabel 1. Karakteristik Responden Berdasarkan Umur

\begin{tabular}{cccc}
\hline No & Umur Responden & Frekuensi (n) & Persentase (\%) \\
\hline 1 & $26-35$ & 6 & 27.3 \\
\hline 2 & $36-45$ & 5 & 22.7 \\
\hline 3 & $46-55$ & 11 & 50.0 \\
\hline & Total & 22 & 100,0 \\
\hline
\end{tabular}




\section{Hasil Pengamatan Terhadap Subjek Penelitian Berdasarkan Variabel Penelitian}

Hasil pengukuran terhadap 22 responden diperoleh hasil distribusi frekuensi keluhan nyeri punggung bawah pada pengerajin wanci sebelum diberikan terapi bekam kering adalah sebagai berikut:

Tabel 2. Distribusi Frekuensi Keluhan Nyeri Punggung Bawah pada Pengerajin Wanci di Desa Bresela Kecamatan Payangan Sebelum Diberikan Terapi Bekam Kering Tahun 2018.

\begin{tabular}{cc}
\hline Kriteria & $\begin{array}{c}\text { Intensitas nyeri sebelum terapi } \\
\text { bekam kering }\end{array}$ \\
\hline Mean & 3,09 \\
\hline Median & 3,00 \\
\hline Modus & 4,00 \\
\hline Maksimum & 5,00 \\
\hline Minimum & 1,00 \\
\hline
\end{tabular}

Berdasarkan tabel 2, Berdasarkan dari tabel diatas dapat dilihat bahwa hasil distribusi frekuensi keluhan nyeri punggung bawah pada pengerajin wanci sebelum diberikan terapi bekam kering sebagian besar berada dalam skala 4 yaitu sebanyak 8 responden $(36.4 \%)$.

Tabel 3. Distribusi Frekuensi Keluhan Nyeri Punggung Bawah pada Pengerajin Wanci di Desa Bresela Kecamatan Payangan Setelah Diberikan Terapi Bekam Kering Tahun 2018.

\begin{tabular}{ccc}
\hline No & Kriteria & $\begin{array}{c}\text { Intensitas nyeri setelah } \\
\text { terapi bekam kering }\end{array}$ \\
\hline 1 & Mean & 1,50 \\
\hline 2 & Median & 1,00 \\
\hline 3 & Modus & 1,00 \\
\hline 4 & Maksimum & 3,00 \\
\hline 5 & Maksimum & 0,00 \\
\hline
\end{tabular}

Berdasarkan tabel 3, dapat dilihat bahwa rata- rata (mean) skala nyeri responden sebelum diberikan terapi bekam kering adalah 3,09 sedangkan setelah diberikan terapi bekam kering mengalami penurunan rata-rata menjadi 1,50 dan skala nyeri mengalami penurunan dari skala nyeri 4 menjadi skala nyeri 1 .

Tabel 4. Analisa Perubahan Rata- rata Distribusi Frekuensi Keluhan Nyeri Punggung Bawah pada Pengerajin Wanci di Desa Bresela Kecamatan Gianyar Sebelum dan Sesudah Diberikan Terapi Bekam Kering

\begin{tabular}{lcccc}
\hline $\begin{array}{l}\mathrm{N} \\
\mathrm{o}\end{array}$ & Kriteria & $\begin{array}{c}\text { Intensitas Nyeri Sebelum } \\
\text { Terapi Bekam Kering }\end{array}$ & $\begin{array}{c}\text { Intensitas Nyeri Setelah } \\
\text { Terapi Bekam Kering }\end{array}$ & $\begin{array}{c}\text { Perubahan } \\
\text { Intensitas Nyeri }\end{array}$ \\
\hline 1 & Mean & 3,09 & 1,50 & 1,59 \\
\hline 2 & Median & 3,00 & 1,00 & 2,00 \\
\hline 3 & Modus & 4,00 & 1,00 & 3,00 \\
\hline 4 & Maksimum & 5,00 & 3,00 & 2,00 \\
\hline 5 & Minimum & 1,00 & 0,00 & 1,00 \\
\hline
\end{tabular}


Dari tabel 4, Berdasarkan tabel diatas dapat dilihat bahwa rata- rata (mean) skala nyeri responden sebelum diberikan terapi bekam kering adalah 3,09 sedangkan setelah diberikan terapi bekam kering mengalami penurunan rata-rata menjadi 1,50.

Tabel 5. Hasil Uji Wilcoxon Pengaruh Terapi Bekam Kering Terhadap Keluhan Nyeri Punggung Bawah pada Pengerajin Wanci di Desa Bresela Kecamatan Gianyar Tahun 2018

\begin{tabular}{cccccc}
\hline $\begin{array}{c}\text { Variabe } \\
1\end{array}$ & $\mathrm{~N}$ & Mean & $\begin{array}{c}\text { Selisih } \\
\text { mean }\end{array}$ & $\mathrm{Z}$ & P value \\
\hline Pretest & 2 & 3.09 & & & \\
& 2 & & & - & 0.000 \\
& & & & 3,88 & \\
${$\cline { 1 - 2 }$} }$ & 2 & 1,50 & & & \\
& 2 & & & & \\
\hline
\end{tabular}

Hasil analisis data diatas menunjukan bahwa, terapi bekam kering yang diberikan berpengaruh terhadap keluhan nyeri punggung bawah yang dirasakan oleh responden yang ditumjukan dengan nilai $p$ yaitu $0,000(p<0,05)$. Berdasarkan hasil perbandingan skor intensitas nyeri punggung bawah posttest dan pretest pada responden juga diperoleh hasil bahwa, tidak ada tanda ranking pengurangan hasil posttest dan pretest yang bernilai positif dan nol. Seluruh hasil pengurangan ranking posttest dan pretest bernilai negatif dimana ratarata adalah hasil pengurangan ranking posttest dan pretest yang bernilai negatif yaitu 10,00 . Pada tabel diatas juga diperoleh nilai signifikan nilai $\mathrm{p}$-value $=0,000$. Nilai $\mathrm{p}$-value $<\mathrm{a}$, maka kesimpulan Ho ditolak, hal ini berarti $95 \%$ terdapat pengaruh terapi bekam kering terhadap keluhan nyeri punggung bawah pada pengerajin wanci di desa bresela kecamatan gianyar tahun 2017.

\section{PEMBAHASAN}

Pembahasan hasil penelitian ini akan dibahas secara berurutan mulai dari karakterisitik responden berdasarkan umur responden, skala nyeri sebelum dan setelah diberikan terapi bekam serta analisis pengaruh terapi bekam terhadap penurunan skala nyeri. Adapun pembahasan hasil penelitian ini sebagai berikut:

\section{Intensitas Nyeri Punggung Bawah pada Pengerajin Wanci Sebelum Diberikan Terapi Bekam Kering}

Berdasarkan hasil penelitian terhadap keluhan nyeri responden sebelum diberikan terapi bekam kering didapatkan sebelum diberikan terapi bekam kering sebagian besar berada dalam kategori nyeri sedang dengan skala 4 yaitu sebanyak 8 responden $(36,4 \%)$ dengan rata-rata (mean) skala nyeri responden berada pada rentang nyeri 3,09 skala nyeri sedang. Skala nyeri yang berbeda dirasakan oleh subjek penelitian disebabkan karena posisi janggal dalam bekerja, rentang usia, jenis kelamin juga dapat berpengaruh terhadap skala nyeri responden, semakin tua usia maka semakin tinggi resiko nyeri yang dirasakan. Jenis kelamin perempuan lebih rentan terkan nyeri punggung bawah karena kepadatan tulang perempuan lebih rendah daripada laki-laki.

\section{Intensitas Nyeri Punggung Bawah pada Pengerajin wanci Setelah Diberikan Terapi Bekam Kering}

Setelah diberikan terapi bekam kering didapatkan hasil distribusi frekuensi keluhan nyeri punggung bawah pada pengerajin wanci sebagian besar berada dalam kategori 
intensitas nyeri 1 yaitu sebanyak 8 responden (36,4\%). Dengan rata-rata intensitas skala nyeri responden berada pada skala 1,50 dan rata-rata penurunan intensitas nyeri setelah diberikan terapi bekam kering adalah 1,59. Berdasarkan penjelasan diatas dapat disimpulkan bahwa terjadi penurunan rata-rata intensitas nyeri responden setelah diberikan terapi bekam kering. Penurunan intensitas nyeri tersebut disebabkan karena efek relaksasi yang ditimbulkan dari terapi bekam kering.

\section{Pengaruh terapi bekam kering terhadap keluhan nyeri punggung bawah pada pengerajin wanci di desa bresela kecamatan payangan}

Hasil penelitian terapi bekam kering terhadap keluhan nyeri punggung bawah pada pengerajin wanci menunjukan nilai signifikansi $P$-value $0,000<a \mathrm{a}, 05$, maka kesimpulan Ho ditolak, hal ini berarti ada pengaruh terapi bekam kering terhadap keluhan nyeri punggung bawah pada pengerajin wanci di Desa Bresela Kecamatan Payangan.

Terapi bekam kering dapat memunculkan respon relaksasi, respon relaksasi ini terjadi apabila dilakukan pembekaman pada satu poin. Melalui terapi bekam penyebab nyeri punggung bawah yang disebabkan oleh spasme otot dan vasospasme pembuluh darah dapat memunculkan respon relaksasi (Umar, 2010)

Efek relaksasi akan diteruskan ke hipotalamus untuk menghasilkan Cortocotrophin Releasing Factor (CRF) serta releasing factors lainnya oleh adenohipofise. Selanjutnya CRF merangsang kelenjar pituitary untuk meningkatkan prodiksi Proopoiodmelanocortin (POMC) sehingga produksi enkephalin oleh medulla adrenal meningkat. Enkefalin adalah peptide kecil yang menyebabkan inhibisi prasinaps serabut tipe $C$ dan A-delta di spina. Inhibisi ini mengurangi penyaluran stimulus nyeri keluar medulla spinalis sehingga dapat mengurangi rasa nyeri. Selain itu CRF akan menyebabkan terbentuknya ACTH, corticotrophin, corticosteroid. Corticosteroid ini mempunyai efek menyembuhkan peradangan serta menstabilkan permeabelitas sel (Umar, 2010).

Penelitian lainnya menunjukan bahwa pembekaman di kulit akan menstimulasi kuat saraf permukaan kulit yang akan dilanjutkan pada cornu posterior medulla spinalis melalui saraf A-delta dan C, serta traktus spina thalamicus kearah thalamus yang akan menghasilkan endorphin sehingga produksi endorphin meningkat. Sedangkan sebagian rangsangan lainnya akan diteruskan melalui serabut aferen simoatik menuju ke motor neuron dan menimbulkan reflek intubasi nyeri. Dengan meningkatnya produksi enkepalin dan endorphin dapat menghambat penyaluran stimulus nyeri sehingga sensasi nyeri menjadi berkuran (Umar, 2010).

Berdasarkan hasil obervasi yang dilakukan di lapangan, rata-rata pengerajin bekerja dengan posisi duduk yang lama dan posisi membungkuk. Pengerajin dalam pembuatan wanci ini melakukan proses yang bertahap yaitu dari menentukan bahan, membuat cetakan dan sampai proses finishing yaitu proses pengecatan agar wanci tersebut terlihat menarik dan laku terjual. Semua proses tersebut dilakukan dengan cara posisi yang tidak ergonomis yaitu duduk dan membungkuk sehingga posisi yang tidak ergonomis tersebut dapat menimbulkan nyeri pada punggung bagian bawah sehingga semua pengerajin mengeluhkan nyeri punggung bagian bawah dan rata-rata pengerajin mengalami nyeri sedang (skala nyeri 4). Hal tersebut sejalan dengan penelitian Nurwahyuni (2012) yang melaporkan bahwa persentase tertinggi responden yang mengalami keluhan nyeri punggung bawah dengan skala nyeri sedang adalah pekerja dengan posisi yang tidak ergonomis.

Dari uraian diatas maka dapat disimpulkan bahwa terapi bekam efektif dalam menurunkan nyeri. Terapi bekam yang hanya dapat memunculkan respon relaksasi sangat cocok diberikan untuk skala nyeri ringan yang dikeluhkan oleh pekerja pengangkut sampah. Dengan memberikan terapi bekam pada suatu titik yaitu titik lokal sekitar 
punggung bawah yaitu Du4, Du3, G30, B23, dan B26 akan menimbulkan efek relaksasi. Pemberian terapi bekam kering sebagai salah satu terapi komplementer bermannfaat untuk memperlancar mikrosirkulasi darah, melepaskan neurotransmitter, dan mengeluarkan hormone yang dapat meringankan nyeri yang dirasakan pekerja pengerajin wanci.

\section{SIMPULAN} berikut:

Berdasarkan tujuan khusus penelitian ini dapat disimpulkan beberapa hal sebagai

1. Rata-rata (mean) skala nyeri sebelum diberikan terapi bekam kering berada pada skala 3,09 yaitu sebanyak 8 responden $(36,4 \%)$.

2. Rata-rata skala nyeri setelah diberikan terapi bekam kering berada pada skala 1,50 yaitu sebanyak 14 responden (36,8\%).

3. Ada pengaruh terapi bekam kering terhadap keluhan nyeri punggung bawah pada pengerajin wanci di Desa Bresela Kecamatan Payangan dengan nilai $p=0,000(<0,05)$.

\section{SARAN}

\section{Kepada Institusi Pendidikan}

Memasukkan materi terapi komplementer yang salah satunya adalah terapi bekam kering kedalam mata kuliah keperawatan, sehingga mahasiswa dapat memahami bahwa dengan pemberian terapi bekam kering dapat meringankan rasa nyeri pada punggung bawah.

\section{Kepada Responden}

Penelitian ini membuktikan bahwa terapi bekam efektif untuk mengatasi nyeri punggung bawah. Pengerajin yang mengalami nyeri punggung bawah dapat menggunakan terapi bekam kering yang bisa diperoleh di tempat-tempat praktik mandiri perawat terapi bekam, tanpa harus menggunakan terapi farmakologis atau obat- obatan yang menimbulkan efek samping yang lebih berbahaya daripada terapi bekam. Selain itu pengerajin wanci sebaiknya merubah posisi kerja yang selalu membungkuk dengan menggunakan meja sebagai alas bahan wanci yang akan diproses sehingga posisi bekerja tidak membungkuk.

\section{Kepada Petugas Kesehatan (Puskesmas Payangan)}

Diharapkan kepada petugas kesehatan agar mengaplikasikan program pelayanan kesehatan tradisional komplementer contohnya terapi bekam kering dalam menangani keluhan nyeri sehingga klien tidak harus diberikan obat-obatan yang dapat menimbulkan efek samping yang lebih serius daripada terapi bekam.

\section{Kepada Peneliti Selanjutnya}

1. Kepada peneliti lain yang terkait untuk mengembangkan penelitian ini agar menggunakan kelompok kontrol atau kelompok pembanding, sehingga ada pembanding terhadap sampel penelitian.

2. Mengontrol faktor-faktor yang mempengaruhi nyeri yang dirasakan responden seperti usia, jenis kelamin, kebudayaan, perhatian ansietas, pola koping dan dukungan keluarga yang dapat mempengaruhi hasil penelitian. 


\section{DAFTAR PUSTAKA}

Anies. 2014. Kedokteran Okupasi Berbagai Penyakit Akibat Kerja dan Upaya Penanggulangan dari Aspek Kedokteran. Yogyakarta: Ar-Ruzz Media.

Bimariotejo. 2009. Low Back Pain (LBP). www.backpainforum.com 18 mei 2016.

Nursalam. 2011. Konsep dan Penerapan Metodelogi Penelitian Ilmu Keperawatan, Pedoman Skripsi, Tesis dan Istrumen, Edisi 2. Jakarta: Salemba Medika.

2013. Konsep dan Penerapan Metodelogi Penelitian Ilmu Keperawatan, Pedoman Skripsi, Tesis dan Istrumen, Edisi 3. Jakarta: Salemba Medika.

Purnamasari, H. d. 2010. Overweight Sebagai Faktor Resiko Low Back Pain Pada Pasien Poli Saraf RSUD Prof. Dr.Margono Soekarjo Purwokerto. Mandala of Health Volume 4, Nomor 1, Januari 2010.

Sugiyono, 2017. Metode Penelitian Kuantitatif, Kualitatif dan $R \mathcal{E}$ D. Bandung : Penerbit alfabeta

Tjiptoheriyanto, P. 2008. Pengembangan Sumber Daya Manusia. Jakarta: LIPPI Press.

Umar, W. 2010. Bebas Stroke dengan Bekam. Surakarta: Thibbia. 